International Research Journal of Engineering, IT \& Scientific Research
Available online at https://sloap.org/journals/index.php/irjeis/
Vol. 7 No. 1, January 2021, pages: 10-24
ISSN: 2454-2261
https://doi.org/10.21744/irjeis.v7n1.1200

\title{
Design of a Photovoltaic Power Plant Connected to the Grid to Cover the Daytime Energy Demand of the Jenmer Cia Ltda Service Station
}

\author{
Antonio Vázquez Pérez ${ }^{a}$ \\ Fabián Ignacio Carpio Zambrano ${ }^{b}$ \\ Alcira Magdalena Velez Quiroz ${ }^{\mathrm{c}}$ \\ Gino Mieles Mieles d \\ Carlos Gustavo F. Villacreses Viteri ${ }^{\mathrm{e}}$
}

\section{Article history:}

Submitted: 09 November 2020

Revised: 27 December 2020

Accepted: 18 January 2021

\section{Keywords:}

carbon footprint;

distributed generation;

photovoltaic systems;

renewable energy;

social impact;

\begin{abstract}
The work presents an analysis linked to one of the sustainable energy alternatives that are currently being adopted with success worldwide. Putting the field research method into practice, the results of a study related to an application of technological innovation are shown to reduce the amount of the electricity bill at the JENMER CIA LTDA Service Station, through the introduction of photovoltaic technology connected to the low voltage network of the institution. The results of the study of load and hourly energy consumption of said entity are shown and its methodology is deployed for the technological design of a photovoltaic plant connected to the grid, which can avoid the energy consumption of the conventional grid, reducing the amount of the electricity bill of the institution, at the same time that it is possible to reduce losses, improve the quality of electricity service and reduce COemissions2 into the atmosphere. The energy, economic, environmental, and social impacts associated with the penetration of photovoltaic technology are exposed.
\end{abstract}

International research journal of engineering, IT \& scientific research (c) 2021. This is an open access article under the CC BY-NC-ND license (https://creativecommons.org/licenses/by-nc-nd/4.0/).

Corresponding author:

Antonio Vázquez Pérez,

Ph.D. Student

Universidad Técnica de Manabí- Universidad de Alicante, Portoviejo, Manabí, Ecuador.

Email address: antonio.vazquez@utm.edu.ec

\footnotetext{
a PhD Student, Universidad Técnica de Manabí-Universidad de Alicante, Portoviejo, Manabí, Ecuador

b CNEL, Portoviejo, Ecuador

c Universidad Técnica de Manabí, Portoviejo, Manabí, Ecuador

d Universidad Técnica de Manabí, Portoviejo, Manabí, Ecuador

e PhD Student, Universidad Técnica de Manabí-Universidad de Alicante, Portoviejo, Manabí, Ecuador
} 


\section{Introduction}

Electric energy is undoubtedly the most used resource in the world, it constitutes an element of vital importance for development, however, the intensive use of fossil fuels (oil, gas, and coal), promote the depletion of their reserves, at the same time that they can generate polluting effects that put the stability of life on Earth at stake (Arauz et al., 2017). Man has not always used oil as a preferential source of energy. It is estimated that during the 6th century BC with the beginning of the Neolithic era, the man began to control and rationally use energy in agriculture, as well as the use of animals for work and the preparation of breaths. Already in the 4th and 3rd centuries BC, the first great energy systems in history began, with the construction of crop irrigation systems in the rain zones of the Tigris, the Euphrates, and the Nile. Around this same time, an elementary machine for lifting weights was built based on the principle of the lever (Rodríguez Gámez et al., 2013).

Between the twelfth and seventeenth centuries, there was a strong demand for energy for the processing and preparation of metals, considerably increasing the demand for wood to use as fuel. All of this led to a disproportionate advance in deforestation in many European regions. It is precisely in the seventeenth century when as a result of poor management in the use of wood as fuel, an acute shortage of this resource is experienced in Western Europe, especially in the British Isles, where for the realization of industrial activities derived from thermal energy, it was necessary to start burning coal (Arauz et al., 2016). From the seventeenth century, the first industrial revolution began to develop, with the emergence of technologies such as the steam engine, the railroad, and textile machines, producing the first energy transition, where wood and charcoal were replaced by mineral coal. Some centuries later, between 1860 and 1930, the second energy transition takes place, linked to the second industrial revolution, where electrical systems, aviation, and the steel industry were introduced. In this stage, the mineral coal gives way to the preferential use of oil. As early as 1859, the first well for oil extraction in Pennsylvania had been dug by Seneca Oíl Co (Arauz et al., 2016).

In a short period already in the second half of the 19th century, the participation of oil in the world primary energy market had increased rapidly, and by 1970 it was the basis of the first global energy supply system (Gámez et al., 2017). During the second half of the 20th century, the participation of fossil fuels in energy generation continued to increase and when the scenario of the new energy policies is described, it is suggested that global energy demand registers a strong rise and may increase by one third from 2010 to 2035 (Pérez et al., 2017). The combustion of fossils is responsible for $80 \%$ of the emissions of carbon dioxide $(\mathrm{CO} 2)$ into the atmosphere, generating global warming. Some organizations have published information that reveals the danger posed by the burning of coal, oil, and natural gas since the historical level of $\mathrm{CO} 2$ in the atmosphere had been between 180 to $280 \mathrm{ppm}$ and in just over a hundred years it was has risen to $400 \mathrm{ppm}$, a situation that if not controlled can generate a truly global climate calamity (Medveczky \& Ochoa, 2012).

The increase in excessive dependence on fossil fuels to obtain energy led to the depletion of their reserves, to such an extent that it is estimated according to a study published by the Organization of Petroleum Producing Countries (OPEC), that supply could fail oil for the year 2037 and on the other hand, with a high degree of complexity due to the danger posed by the burning of coal, oil and natural gas for the environment and the human species (Cedeno et al., 2017). As a possible response to these natural impacts and the conservation of man's own life, a social commitment arises sufficiently understood by most human beings, which is committed to a scheme of progress that at the same time is respectful of nature and the human integrity, that is, it is projected for a sustainable development, which promotes, among other elements, renewable sources of energy, which some time ago were not thought to have such important participation in terms of electricity generation (Zahedi, 2006). International discussions about the causes and implications for humanity of the so-called "greenhouse effect", caused by the increasing emissions into the atmosphere of gases such as $\mathrm{CO} 2$, reflect the need for a comprehensive approach in the treatment of environmental problems and development, as well as the need for concerted action by the international community to mitigate the effects of global warming (Cedeno et al., 2017).

For some years, it has been strongly argued that renewable sources of energy that replace fossil fuels should be cleaner and should not produce more impacts that accelerate climate change. It is emphasized that as an additional advantage they should be located easily, with the least impact on the landscape and environmental conditions (Van, 2002). The answer lies in the environment: sunlight, wind, water, plants, the heat of the Earth. Some of these sources are very old. Since human beings learned to make fire, they used wood to heat and cook. Windmills helped irrigate the fields of the ancient Persians. The ancient Greeks and Romans used the falling water to turn water wheels. However, at the beginning of the 20th century, in many places, supposedly cheaper fossil fuels, replaced almost all of these traditional sources of energy supply (Rodríguez Gámez et al, 2013). Solar radiation is the main source of

Pérez, A. V., Zambrano, F. I. C., Quiroz, A. M. V., Mieles, G. M., \& Viteri, C. G. F. V. (2021). Design of a photovoltaic power plant connected to the grid to cover the daytime energy demand of the Jenmer cia ltda service station. International Research Journal of Engineering, IT \& Scientific Research, 7(1), 10-24. https://doi.org/10.21744/irjeis.v7n1.1200 
primary energy on Earth, which is transformed into electrical energy by photovoltaic conversion. It is practically inexhaustible, non-polluting, it is territorially distributed and its potential availability is much higher than the energy needs of man (Giraudy et al., 2014).

Unlike fossil fuels, solar energy does not produce carbon dioxide and therefore does not contribute to global warming. The most important thing is that unlike increasingly scarce fossil fuels, this source of energy will never end as long as man exists on the planet (Sarmiento et al., 2014). Globally, there is a growing awareness of the importance of renewable energy and energy efficiency, which constitute an alternative not only to address climate change but to create new economic opportunities and provide access to energy to billions of people (REN 21, 2015). At present, the irruption of renewable energy sources in the international energy scene is evident. The proper use of solar modules favors the preservation of natural resources, saving oil and minimizing the environmental impact derived from electricity generation.

Since the applications of photovoltaic technology began at the beginning of the 20th century, their main destination was in the aerospace career and later they were used to guarantee service in isolated regions or sites of the electrical network. Recently there has been a boom in photovoltaic applications connected to the grid, mainly in Europe, and at present, they have practically become widespread worldwide. Photovoltaic technology takes advantage of solar radiation as fuel for the generation of electrical energy and thus allows to take advantage of the benefits of this service, where among the advantages it is possible to obtain a reduction in the electricity bill by reducing the electricity consumption of the conventional network it is possible to reduce pollution by greenhouse gas emissions, to generate electricity with a virtual cost equal to zero for fuel consumption, to reduce losses and to regionalize the generation of electricity, alleviating the economic subsidy that the Ecuadorian state intended to ensure electricity service. From a technical point of view, photovoltaic technology can benefit the electrical voltage profile where it is installed. During the past decade and particularly in recent years, there have been possible advances in renewable energy source technologies, increases in generation capacity worldwide, as well as rapid cost reductions thanks to the support provided by economic policies, which have attracted a significant amount of investments and driven down costs through economies of scale (REN 21, 2015).

Renewable energy continued to develop in 2014, even with growing global energy consumption and the dramatic decline in oil prices during the second half of 2015 as a backdrop. Also in 2014, renewable energy expanded significantly in terms of installed capacity and energy produced; while investments in renewable energy in the energy sector exceeded net investments for fossil fuel power plants. The fastest growth and the most substantial increase in renewable capacity worldwide were seen in the electricity sector, the dominant technologies were: wind, solar photovoltaic (PV), and hydropower (REN 21, 2015). Policy support for renewable energy has contributed to market volume growth and high global competition. Significant cost reductions, especially for solar PV and wind, have played a role in the increasing electrification of transportation and heating appliances. This fact has also highlighted the potential for greater overlap between sectors shortly. In many countries, renewable energies are highly competitive with conventional fuels, particularly in the electricity sector (REN 21, 2015). In developing countries, distributed power generation systems offer an unprecedented opportunity to accelerate the transition to modern energy services and increase access (Cabeza, 2018; Dincer, 2000; Panwar et al., 2011).

For its part, the Ecuadorian government closely follows the use of renewable energy sources with hydro, wind, and solar generation projects in various sectors of the country. But the national bet is still focused on taking advantage of its water potential with large projects and investments. In Loja, the Villonaco Wind Farm is the largest project of its kind in the country, with 11 installed wind turbines that provide energy to the medium voltage distribution network. This equipment will generate $16.5 \mathrm{MWh}$ and their contribution to the country will be $0.03 \%$ to the National Interconnected System, being able to avoid the emission of 38,000t CO2 as well as the importation of a significant volume of diesel. These projects are promoted through Renewable Energy (Chilan et al., 2017; ElGhonemy, 2012).

Ecuador has caught up with the latest in photovoltaic and thermal technology. As an example, the Government implemented photovoltaic solar panels in eight communes in the Gulf of Guayaquil. The Eurosolar project aims to provide electricity to 91 isolated and poor communities with the help of the European Union. Although other projects have been developed through the introduction of facilities greater than 500kWp, (Pérez et al., 2016). However, the contribution of photovoltaic systems connected to the low voltage grid in the distributed generation model is still poor and its essence and objectives are not adequately understood. To obtain the expected results in a photovoltaic project, certain factors must be considered, which must be studied and analyzed in detail. The main thing to assess is the energy efficiency of the photovoltaic system to be installed, to achieve this, different elements must be evaluated that are related, such as the dimensions of the technology installation area, the average potential of daily solar 
energy, the angle of inclination of the modules, the level of shading present in the area, the quality and characteristics of the technology offered, the evaluation of the possible damages caused by natural disasters and other aspects that in a particular way can be analyzed (Rodriguez et al., 2016).

The objective of the research is to offer a sustainable alternative to the problem of energy supply, where the results of the technical design of a photovoltaic system connected to the grid at the JENMER CIA LTDA Service Station are exposed, which offers the possibility of reducing dependence on oil in the generation of electricity, contributing to the reduction of COemissions 2 into the atmosphere. The base generation in the province of Manabí depends on the use of oil through an inefficient and very expensive centralized system. This supposes a negative environmental and economic influence on energy consumption, since for every MWh of electricity generated with thermal plants, up to 0.9 tons of COcan be emitted 2 into the atmosphere, at the same time that oil is a resource that presents very unstable prices with an upward trend in the market, causing the electricity service to be inefficient and expensive.

The electricity company has considered achieving a relevant social impact by increasing the supply of energy and despite the use of various technologies aimed at guaranteeing quality service, this last objective is achieved at a high economic and environmental price, since they are increasingly more numerous technologies are incorporated to achieve this, without fully achieving the proposed objectives. The so-called renewable sources of energy, thus known for their agile and natural ability to generate themselves, cover only $12.9 \%$ of the global energy demand worldwide. This last percentage is broken down as follows: biomass with energy generated with organic elements derived from crops $(10.2 \%)$ hydraulic $(2.3 \%)$; wind energy $(0.2 \%)$; geothermal and solar $(0.2 \%)$.

The various reforms carried out in Ecuador have been generating a whole procedure that favors energy saving, but nothing forceful and specific as something as clear and efficient as clean energy. For this, the Technical University of Manabí, in its academic and research development plans, defines projects that involve private spaces, which complement the programs that help increase renewable energies, transforming the energy monopoly by a renewable matrix of distributed and sustained generation in the use of renewable sources that are available in the territories (Cabeza, 2018). In the province of Manabí and especially in the city of Portoviejo, photovoltaic energy can guarantee a quality electrical service, reducing the economic and environmental impact in the generation of electricity, elements that constitute a challenge for the Technical University of Manabí. At the Jenmer CIA LTDA Service Station, there is a high billing for electricity consumption of the national interconnected system; which has caused concern; Therefore, the management of the entity considers it necessary to study the introduction of a project that seeks to put into operation a photovoltaic system connected directly to the institution's low-voltage network, which allows its generation to reduce expenses for electricity billing. and at the same time contribute to savings in oil consumption, reduce COemissions 2 from electricity generation, reduce losses and increase the quality and reliability of electricity service.

On the part of the Technical University of Manabí, several study projects are carried out for the introduction of photovoltaic energy, as is the case of the Jenmer CIA LTDA Service Station. In this project, an already implemented methodology (SIGDS) (María, 2015) is presented, which allows the saving of electricity consumption in a fairly reasonable percentage in the hours of greatest demand for the benefit of the same institution. This implies that there will be greater savings for the entity, with the use and environmental help that the project provides, assuming the management and motivation of the authorities to support the introduction of renewable sources of energy (Cabeza, 2018). Likewise, each energy management and saving project, no matter how small, must establish requirements, norms, and standards, which seek to ensure that the new projects that are prepared, tendered and built, comply with the current studies in force based on achieving greater efficiency, save natural resources and reduce environmental impacts derived from energy generation (Cabeza, 2018). The introduction of a photovoltaic system to supply electricity to the Jenmer CIA LTDA Service Station can contribute to the reduction of expenses for electricity billing and at the same time promote savings in oil consumption, contribute to reducing the $\mathrm{CO}_{2}$ emissions from 2 electricity generation, and increase the quality and reliability of electricity service.

\section{Materials and Methods}

It corresponds to descriptive research since it is about obtaining information about photovoltaic systems, especially those that are connected to the low voltage network in the distributed generation model and its application in the context of the Power Station (Joerissen et al., 2004; Fabjan et al., 2001). Servicios Jenmer CIA LTDA, to reduce the amount of the electricity bill, at the same time to achieve a reduction in oil consumption and reduce $\mathrm{CO} 2$ emissions 2

Pérez, A. V., Zambrano, F. I. C., Quiroz, A. M. V., Mieles, G. M., \& Viteri, C. G. F. V. (2021). Design of a photovoltaic power plant connected to the grid to cover the daytime energy demand of the Jenmer cia ltda service station. International Research Journal of Engineering, IT \& Scientific Research, 7(1), 10-24. https://doi.org/10.21744/irjeis.v7n1.1200 
into the atmosphere from electricity generation. The basic method used is the exploratory one, to determine a group of data and situations that were unknown, among which are: The hourly consumption of electricity at the Jenmer CIA LTDA Service Station; The incident solar potential at the installation site, and; the specific productivity that can be achieved. Analysis-synthesis was also used in the study of bibliographic references; the historical-logical to offer precise thoughts related to the logic of scientific-technical development on the subject related to the study of photovoltaic technology and the role it can play in reducing the electricity bill. The inductive-deductive allowed, from the presence of the content of the object of study to the elaboration of own conclusions, thus making it possible to offer the particularities and the proposed solutions. The theoretical-mathematical method to demonstrate from the theory, the effectiveness of the technical procedure for checking and controlling the models related to the design of the photovoltaic power plant and the definition of the economic, environmental, and social impacts.

The techniques generally used the investigative techniques of revision of documents, texts, theses, books, newspapers, magazines, technical standards, web pages, and manuals, to obtain the appropriate and clear information for the proper development of the topic addressed. The interview was used that was directed to the teaching staff of the Electrical Engineering career, focused on students and professors of the career, with basic questions related to energy education, renewable energy sources, photovoltaic energy, and energy efficiency; the bibliographic one that allowed to give greater scientific relevance to the theoretical part of the investigation; To calculate the population and sample, 12 professors and specialists were made up, the sample consisted of 9 professors and specialists, for this selection the equation of Murray and Larry was applied (Murray \& Larry, 2009). The population of students and professors of the Electrical Engineering career for the survey is 543. The sample was defined by applying equation 1.

Where:

$$
n=\frac{Z^{2} P Q N}{Z^{2} \cdot P Q N e^{2}}
$$

$\mathrm{n} \rightarrow$ Sample size

$\mathrm{Z} \rightarrow$ Confidence level

$\mathrm{P} \rightarrow$ Probability of occurrence $=0.5$

$\mathrm{Q} \rightarrow$ Probability of non-occurrence $=0.5$

$\mathrm{N} \rightarrow$ Population or universe

\section{Results and Discussions}

The study was carried out at the Jenmer CIA LTDA Service Station, which is located in km 4 via Crucita. The province of Manabí constitutes one of the few territories in Ecuador where most of the electrical energy consumed is of thermal origin, based on the industrial use of oil. In recent years, the territory has been undergoing significant changes in the electrical structural scheme and plans to reduce dependence on oil in electricity generation, as well as to improve energy quality, for which the use of renewable sources is foreseen where solar energy is included through the introduction of photovoltaic technologies.

Since 2015, the Technical University of Manabí has been developing various projects focused on the use of solar energy, especially through the application of photovoltaic technologies, which is why, in that same year, it was possible to introduce a photovoltaic plant connected to the grid in Building No. 3 of full-time teachers of the educational institution (Quijije \& Reina, 2016; Gabriela \& Susana, 2015). In 2016, several studies were carried out related to the application of photovoltaic technology to reduce the effects of an intense earthquake, as well as to raise the quality of electricity in rural areas where the electricity service arrives, but which are facing difficulties with the quality of it (Macías \& Macías, 2016; Delgado, 2016).

In 2017, work continued on the line of research related to the application of photovoltaic technologies and projects associated with the study of solar potential and the application of technology were developed to reduce oil consumption, reduce the amount of electricity bill of users and contribute to the reduction of COemissions 2 into the atmosphere (Espinoza \& Macías, 2016). On the other hand, in recent years there has been a gradual increase in electricity consumption at the Jenmer CIA LTDA Service Station, which has led to the entity's management projecting itself by searching for possible solutions that favor the increased efficiency, energy-saving, and at the same time reducing the economic impact derived from the consumption of electricity served by the CNEL company. 
Variables that can affect solar radiation

Among the variables that can most affect solar radiation is cloudiness. The estimation of energy generation must consider the unstable nature of the primary source (the Sun), which presents fluctuations during the day due to the cloudiness that supposes a high variability, increasing or decreasing according to the seasons of the year, and specifically, in some territories, it may be higher or lower. Solar potential means the equivalent power of solar energy that reaches the horizontal plane of the earth in one day and is expressed in $\mathrm{kWh} / \mathrm{m} 2$ day. The province of Manabí has one of the highest values of solar potential that affects Ecuador as an average. The average intensity of solar radiation in the province is equivalent to half a liter of oil per square meter daily (Rodríguez \& Vázquez, 2018). The first results were the opinions provided by the specialists based on the possibility of improving the electrical service by applying photovoltaic technology, figure 1 is shown.

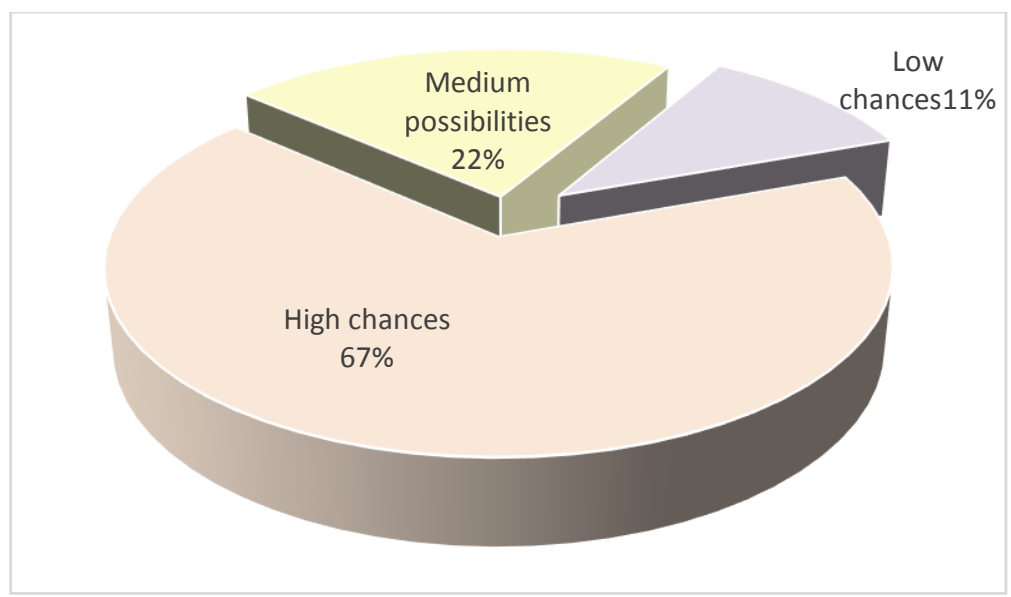

Figure 1. Opinions provided by the specialists

Source: Source: Teachers of the Technical University of Manabí

Se You can see that most of the teachers interviewed believed that the possibility of improving electricity service through the application of solar energy technology is high, in addition to arguing that electricity generation systems using solar energy are based on the capacity of the Photovoltaic cells transform light radiation from the Sun into electrical energy in the form of direct current (DC). This means that the consumption of any other fuel for generation is zero and therefore COemissions 2 are practically symbolic. In a system connected to the grid, this energy through the use of an inverter is transformed into alternating current, which can be used in homes or institutions with the ability to avoid fossil fuels to generate electricity and improve the grid voltage profile together with other benefits that are only achieved with the use of solar energy in the distributed generation mode (Soto, 2005). The foregoing was corroborated through the development of a research project carried out at the Faculty of Mathematical, Physical, and Chemical Sciences of the Technical University of Manabí from the end of 2015 and the beginning of 2016 (Quijije \& Reina, 2016), were carried out measurements with a network analyzer before and after connecting the photovoltaic system and as a result, it was found that after the installation of the technology, the voltage profile and stability of the energy in the network was benefited during the hours of the day when solar energy is available (Gabriela \& Susana, 2015). Considering the above, it can be defined that the introduction of solar energy in the technical format of connection to the low voltage network, taking advantage of the distributed generation mode, can achieve oil savings, reducing the institution's electricity bill. and at the same time contribute to the reduction of $\mathrm{CO}_{2}$ emissions into the atmosphere. It was also obtained that the specialists agreed that photovoltaic technology helps to preserve natural resources figure 2 shows the results obtained.

Pérez, A. V., Zambrano, F. I. C., Quiroz, A. M. V., Mieles, G. M., \& Viteri, C. G. F. V. (2021). Design of a photovoltaic power plant connected to the grid to cover the daytime energy demand of the Jenmer cia ltda service station. International Research Journal of Engineering, IT \& Scientific Research, 7(1), 10-24. https://doi.org/10.21744/irjeis.v7n1.1200 


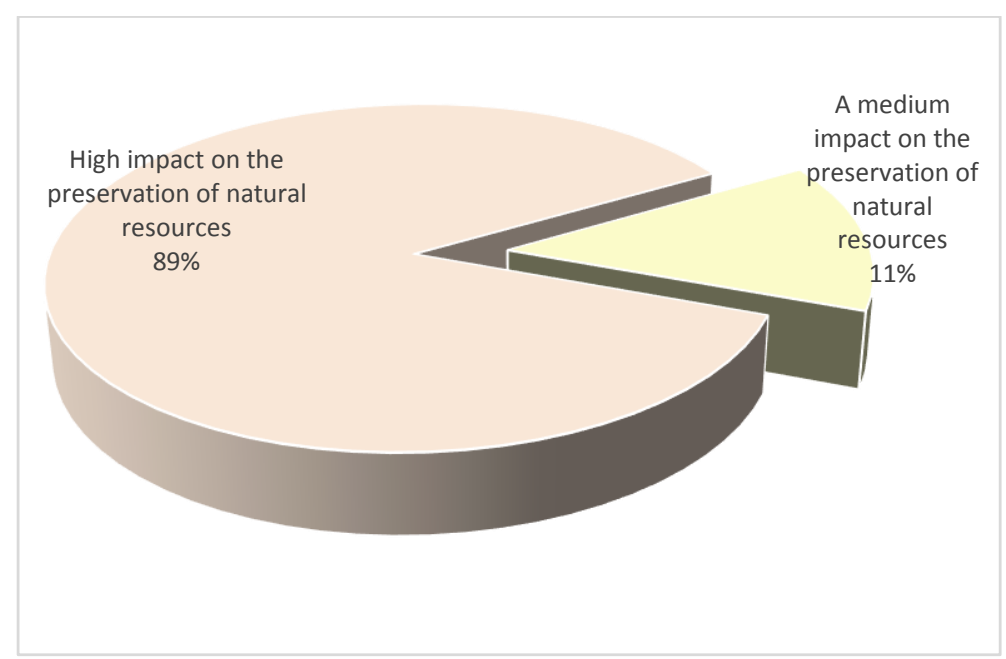

Figure 2. Graphic relationship of the opinions contributed by the specialists

It was found that The almost absolute majority of the specialists surveyed believed that solar energy can have a high impact on the preservation of natural resources since in the province of Manabí electricity generation has a thermal origin through the use of oil and it is known that the fuel consumption rate for electricity generation is approximately 0.25 tonnes of oil for each MWh of electricity generated ( 0.25 tonnes/MWh). This means that for every $4 \mathrm{MWh}$ of photovoltaic energy that can be generated, a ton of oil is being saved. The foregoing shows the high impact that photovoltaic energy can have on the preservation of natural resources. With what has been analyzed above, it can be confirmed by the results of an investigation carried out at the Technical University of Manabí under the title: "Technical evaluation of the work regime and operational efficiency of the $3.4 \mathrm{kWp}$ photovoltaic plant installed in building 3 of teachers from the Technical University of Manabí, where it was found that a small power of photovoltaic technology in operation had been able to generate more than $6 \mathrm{MWh}$ of electrical energy in just over a year of operations, which is equivalent to saving 1,5 tons of oil.

\section{Economic savings}

At present, the reducing effect that favors the introduction of photovoltaic technology connected to the network, for the energy consumption of the conventional system, is known. There are research results carried out at the UTM (Quijije \& Reina, 2016) that show that more than $90 \%$ of the electricity consumption in the institution is carried out during daylight hours when the solar potential is available to be used. To define the economic savings due to the reduction of the electricity bill, equation 2 was used.

$$
R f e=E f v G \cdot \operatorname{Pr} E
$$

Where:

$\mathrm{Rfe} \rightarrow$ amount of electricity bill reduction (USD)

$\mathrm{EfvG} \rightarrow$ photovoltaic energy generated and incorporated into self-consumption $(\mathrm{kWh})$

$\mathrm{PrE} \rightarrow$ referential price of energy (USD / kWh)

Equation 3 was used to define the economic savings to the state from photovoltaic generation.

$$
A e E=E f v G+P e * C E
$$

Where:

$\mathrm{AeE} \rightarrow$ economic savings for the state (USD)

$\mathrm{Pe} \rightarrow$ energy losses avoided $(\mathrm{kWh})$

$\mathrm{CE} \rightarrow$ real cost of thermal energy served to users (USD / $\mathrm{kWh}$ ) 
Preparation of the results report

The Jenmer CIA LTDA Service Station develops its service activities 24 hours a day, however, it can be stated that more than $77.9 \%$ of the institution's energy consumption is concentrated in the hours that solar radiation is available to be used for the generation of electricity. The consumption of electricity is causing the institution to pay the CNEL company a monthly bill for electricity consumption that has increased in recent months, so the university authorities have planned to find a solution that can reduce the amount of said invoice.

\section{Study of the load}

As part of the research, a study of the load of the JENMER CIA LTDA service station was carried out, for which an inventory of the consumer equipment and the calculation of daily consumption was made. To estimate the energy consumption by equipment, the coincidence factor was determined, which indicates the estimated percentage that is considered so that the equipment is consuming energy at the same time as the rest of the electrical equipment. The coincidence factor for each piece of equipment is shown in table 4. For the calculations of installed power (W), the inventory of each piece of equipment by type with its nominal unit power and the amount of equipment that exist was applied, and the equation 4.

$$
P=C e * P n u
$$

Where:

$\mathrm{P} \rightarrow$ power $(\mathrm{kW})$

$\mathrm{Ce} \rightarrow$ number of teams (U)

$\mathrm{Pnu} \rightarrow$ nominal unit power $(\mathrm{kW})$

To estimate the daily working hours, equation 5 was applied.

$$
h T=C e * P n u
$$

Where:

$$
\begin{aligned}
& \mathrm{hT} \rightarrow \text { working hours }(\mathrm{h}) \\
& \mathrm{Fu} \rightarrow \text { utilization factor }(\%) \\
& \mathrm{hD} \rightarrow \text { daily hour }(12)
\end{aligned}
$$

To define the estimate of energy consumption, equation 6 was applied, which would be valid for working days, since it is known that the center ceases its work on weekends and during holidays.

$$
C e=h * D P p
$$

Where:

$\mathrm{Ce} \rightarrow$ estimated energy consumption $(\mathrm{kWh})$

$\mathrm{h} \rightarrow$ working hours (h)

$\mathrm{DPp} \rightarrow$ average power demand $(\mathrm{kW})$

The results of the load study showed that in a normal working day, an average of $475.92 \mathrm{kWh}$ can be consumed, of which $370.89 \mathrm{kWh}$ are consumed in daytime hours when solar energy is available to be used, this represents $77.9 \%$ of the total energy consumed in a day. Figure 3 shows a graph with the hourly behavior of the estimated electricity consumption at the JENMER CIA LTDA service station.

Pérez, A. V., Zambrano, F. I. C., Quiroz, A. M. V., Mieles, G. M., \& Viteri, C. G. F. V. (2021). Design of a photovoltaic power plant connected to the grid to cover the daytime energy demand of the Jenmer cia ltda service station. International Research Journal of Engineering, IT \& Scientific Research, 7(1), 10-24. https://doi.org/10.21744/irjeis.v7n1.1200 


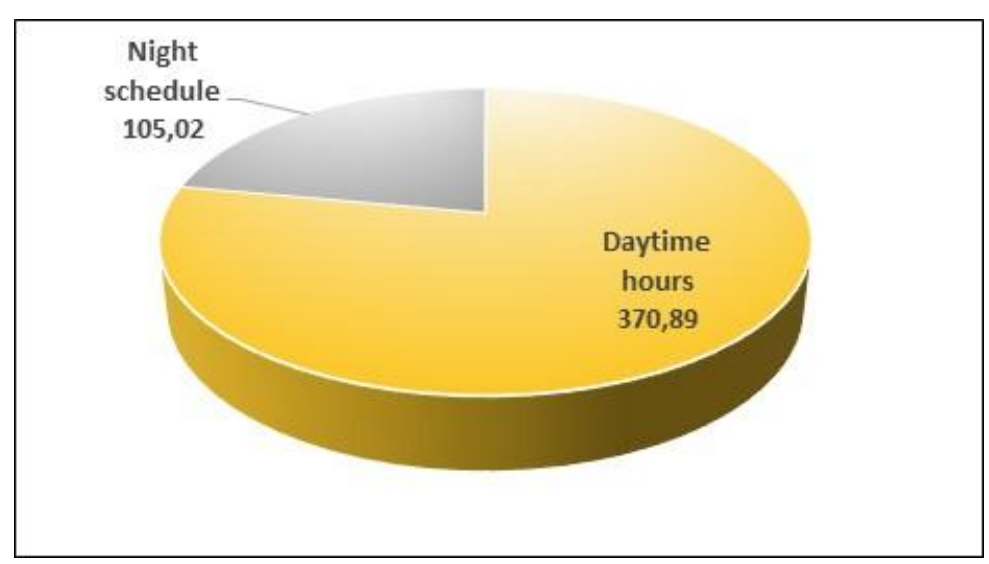

Figure 3. Hourly behavior of the electric energy consumption estimate

\section{Solar potential study}

Another work that needs to be carried out to design a photovoltaic installation to be installed in an institution is related to the study of the solar potential at the installation site. Table 1 shows the calculation of the average solar radiation by months of the incident year at the site where the JENMER CIA LTDA service station is located.

Table 1

Average solar radiation by months of the year

\begin{tabular}{|c|c|c|c|c|c|c|c|c|c|c|c|c|}
\hline $\begin{array}{l}\text { Annual } \\
\text { average } \\
\left(\mathrm{kWh} / \mathrm{m}^{2}\right. \\
\text { day) }\end{array}$ & Jan & Feb & Mar & April & May & June & July & Aug & Sep & Oct & Nov & Dec \\
\hline 4,880 & 5,3 & 5,24 & 5,92 & 5,81 & 5,26 & 4,08 & 4,00 & 4,23 & 4,49 & 4,54 & 4,630 & 5,05 \\
\hline
\end{tabular}

Source: (María, 2015)

Calculation of the necessary power to install

Another of the data that is necessary to calculate is that related to normalized productivity and has been carried out using equation 7 .

$$
P n=P s p a * P F V * A c c * \eta t * \eta c
$$

Where:

$\mathrm{Pn} \rightarrow$ normalized productivity $(\mathrm{kWh} / \mathrm{kWp}$ day)

Pspa $\rightarrow$ annual average solar potential $(\mathrm{kWh} / \mathrm{m} 2$ day)

$\mathrm{PFV} \rightarrow$ photovoltaic power $(\mathrm{kWp})$

Acc $\rightarrow$ solar catchment area for photovoltaic cells $(6.4 \mathrm{~m} 2)$

$\eta \mathrm{t} \rightarrow$ technical efficiency of the modules (when it comes to polycrystalline silicon it is equal to $13 \%$. If it is to monocrystalline silicon it is equal to $16 \%$ )

$\eta \mathrm{c} \rightarrow$ average efficiency of radiation captures during the life cycle (86\%)

Table 2 shows the calculation of the normalized productivity in the site chosen for the study, according to the incident solar radiation in the months of the year. 
Table 2

Calculation of normalized productivity

\begin{tabular}{|c|c|c|c|c|c|c|c|c|c|c|c|c|}
\hline $\begin{array}{c}\text { Annual } \\
\text { average } \\
\left(\mathrm{kWh} / \mathrm{m}^{2}\right. \\
\text { day) }\end{array}$ & Jan & Feb & Mar & April & May & June & July & Aug & Sep & Oct & Nov & Dec \\
\hline 4,347 & 4,722 & 4,668 & 5,274 & 5,176 & 4,686 & 3,635 & 3,564 & 3,768 & 4,000 & 4,045 & 4,125 & 4,499 \\
\hline
\end{tabular}

Source: (María, 2015)

In this way, it was possible to verify that the annual average $\mathrm{Pn}=4.347 \mathrm{kWh} / \mathrm{kWp}$ day.

It is known that the objective of the introduction of photovoltaic technology in the JENMER CIA LTDA service station is carried out to reduce the electricity consumption of the conventional network by approximately $70 \%$ and if it is considered that the average consumption of Electric power in a normal working day by the institution can be about 475.92 MWh day, and knowing that of this total can be consumed in the hours when solar radiation is available to be used about $370.89 \mathrm{kWh}$ day and that the average normalized productivity at the site where the JENMER CIA LTDA service station is located can be equal to $4,347 \mathrm{kWh} / \mathrm{kWp}$ day, it is possible to calculate the power required to be installed to reduce the amount of the electricity bill. To calculate the photovoltaic power that is required to be installed, equation 8 was used. Verifying that to cover said consumption it is necessary to install a photovoltaic power plant with a power equivalent to $85 \mathrm{kWp}$.

$$
P f v N i=\frac{E C e a}{P n a}
$$

Where:

$\mathrm{PfvNi} \rightarrow$ Photovoltaic power necessary to install $(\mathrm{kWp})$

ECea $\rightarrow$ Estimated electricity consumption in daytime hours in one year (kWh day)

$\mathrm{Pna} \rightarrow$ Normalized productivity in one year ( $\mathrm{kWh} / \mathrm{kWp}$ day)

In this way, it can be estimated that the photovoltaic power required to be installed in the JENMER CIA LTDA service station $=85 \mathrm{kWp}$

\section{Design of the photovoltaic plant}

In general, the photovoltaic plant will be made up of a generator made up of monocrystalline silicon modules of the BS-240-6M7.1 type, manufacturer Bauer Solar Technik, with a power in each module of $240 \mathrm{Wp}$, with 60 photovoltaic cells in series and one efficiency of 16.91\%., PVSYST V5.55 was used for its design (PVsyst, 2020), With the analysis carried out, the results shown in Table 3 were obtained.

Table 3

Pérez, A. V., Zambrano, F. I. C., Quiroz, A. M. V., Mieles, G. M., \& Viteri, C. G. F. V. (2021). Design of a photovoltaic power plant connected to the grid to cover the daytime energy demand of the Jenmer cia ltda service station. International Research Journal of Engineering, IT \& Scientific Research, 7(1), 10-24. https://doi.org/10.21744/irjeis.v7n1.1200 
Main balance of the results

\begin{tabular}{|l|c|c|c|c|c|c|c|c|}
\hline & $\begin{array}{c}\text { GlobHor } \\
\mathrm{kWh} / \mathrm{m}^{2}\end{array}$ & $\begin{array}{c}\text { T Amb } \\
{ }^{\circ} \mathrm{C}\end{array}$ & $\begin{array}{c}\text { Globlnc } \\
\mathrm{kWh} / \mathrm{m}^{2}\end{array}$ & $\begin{array}{c}\text { GlobEff } \\
\mathrm{kW} / \mathrm{h}^{2}{ }^{2}\end{array}$ & $\begin{array}{c}\text { EArray } \\
\mathrm{kW} / \mathrm{h}\end{array}$ & $\begin{array}{c}\text { E_Grid } \\
\mathrm{kWh}\end{array}$ & $\begin{array}{c}\text { EffArrR } \\
\%\end{array}$ & $\begin{array}{c}\text { EffysR } \\
\%\end{array}$ \\
\hline January & 164.3 & 26.00 & 155.8 & 150.2 & 9935 & 9299 & 11.07 & 10.36 \\
February & 146.7 & 26.20 & 141.7 & 136.9 & 8905 & 8325 & 10.91 & 10.20 \\
March & 183.5 & 26.60 & 183.4 & 177.8 & 11674 & 10910 & 11.05 & 10.32 \\
April & 174.3 & 26.60 & 180.7 & 175.4 & 11566 & 10807 & 11.11 & 10.38 \\
May & 163.1 & 26.10 & 174.2 & 169.1 & 11286 & 10549 & 11.24 & 10.51 \\
June & 122.4 & 25.00 & 130.2 & 125.8 & 8555 & 7996 & 11.40 & 10.66 \\
July & 124.0 & 24.60 & 130.2 & 125.7 & 8584 & 8030 & 11.44 & 10.70 \\
August & 131.1 & 24.60 & 135.5 & 130.9 & 8897 & 8319 & 11.39 & 10.65 \\
September & 134.7 & 24.80 & 135.4 & 130.8 & 8862 & 8288 & 11.36 & 10.62 \\
October & 140.7 & 25.00 & 138.3 & 133.1 & 9020 & 8436 & 11.32 & 10.59 \\
November & 138.9 & 25.10 & 133.2 & 128.5 & 8509 & 7954 & 11.08 & 10.36 \\
Decemb & 156.6 & 25.70 & 147.9 & 142.3 & 9455 & 8848 & 11.10 & 10.38 \\
\hline Year & 1780.3 & 25.52 & 1786.7 & 1726.5 & 115248 & 107763 & 11.20 & 10.47 \\
\hline
\end{tabular}

Source: self-made. PVSYST V5.55

Where:

GlobHor $\rightarrow$ Global horizontal irradiation.

$\mathrm{T} \mathrm{Amb} \rightarrow$ Ambient temperature.

GlobInc $\rightarrow$ Incident global irradiation in the receiving plane.

GlobEff $\rightarrow$ Global effective irradiation corrected for AMI and shading.

EArray $\rightarrow$ Effective energy at the generator output.

E_Grid $\rightarrow$ Energy injected into the network.

The design of the photovoltaic plant that is proposed to reduce the amount of the electricity bill at the JENMER CIA LTDA service station, will be connected in parallel to the institution's low voltage network, from the part inside the electrical circuit, in such a way that the total consumption of the photovoltaic energy generated is guaranteed, as well as the contribution to the network of the surplus. Technically it will be made up of the following technical components:

1) A photovoltaic generator of 352 monocrystalline silicon modules with a nominal power of $240 \mathrm{Wp}$. The generator will be arranged with 32 chains in parallel and each with 11 modules in series, with a nominal power of $84.5 \mathrm{kWp}$ and in operating conditions of $75.3 \mathrm{kWp}\left(50^{\circ} \mathrm{C}\right)$, with a $\mathrm{Vmpp}=297 \mathrm{~V}$, Impp $=254 \mathrm{~A}$;

2) Two inverters model IG 500 from the manufacturer Fronius. With a unit power of $40 \mathrm{~kW}$ AC. An operating voltage of 210-420 V, which has a group of protections and a system of following the maximum power point;

3) It is also foreseen to use the appropriate protections for the direct current side and the alternating current side; $6 \mathrm{~mm}^{2}$ solar cables and;

4) The metallic structures of support for the photovoltaic modules.

The investigation has made it possible to calculate that the JENMER CIA LTDA service station can consume approximate $475.92 \mathrm{kWh}$ day of electrical energy in a normal operating day and the proposed photovoltaic plant can cover the consumption of about $300 \mathrm{kWh}$ day, which represents $63 \%$ of the energy avoided from the conventional network.

Energy, economic, environmental and social impacts 
The energy, economic, environmental, and social impact studies are an integral part of the work that must be developed from the conceptual stage of the project since the elements that will be reasoned by the decision-makers depend on their results to assign the financing required for the investment.

It can be affirmed that there is no central photovoltaic equal to another, neither in its technical configuration nor because of the results they provide. Each design is distinguished by a group of factors closely related to sustainability, among which the following stand out:

1) The objectives set for investment, energy, economic, environmental, and social;

2) The energy, economic, environmental, and social problems that would be solved with the installation of the technology;

3) The technical impact on the electrical system of the site where the technology is installed.

4) The economic impact for the state derived from the saving of resources provided by the introduction of photovoltaic technology.

5) The environmental benefits derived from the introduction of technology;

6) The social benefits associated with the introduction of photovoltaic generation.

These factors and others that may arise in a particular way imply that each project requires a specific evaluation, justifying the resources that are invested during the preparation of the studies for the introduction of the technology.

\section{The energy impact}

The main objectives that from the energy point of view were drawn with the project, are focused on the following:

1) Through the contribution of photovoltaic energy to be able to cover approximately $63 \%$ of the energy demand consumed by the JENMER CIA LTDA service station, avoiding the consumption of electricity supplied by the conventional grid.

2) Reduce technical and non-technical losses of the conventional centralized system, which represents a contribution at the institutional level.

3) Reduce oil consumption for the generation of electrical energy, contributing to the preservation of natural resources.

4) Improve the quality of service at the JENMER CIA LTDA service station.

\section{The economic impact}

The amount of energy that a photovoltaic power plant can generate and its final destination is closely linked to the modality and variants that can be adapted to carry out the economic feasibility analysis of an investment of this nature. The main objectives that from the economic point of view were drawn with the project, are focused on the following elements:

1) Reduce the amount of the electricity bill by more than $60 \%$ at the JENMER CIA LTDA service station.

2) Achieve a suitably competitive cost of the $\mathrm{kWh}$ generated with photovoltaic.

3) Relieve the economic burden of the state based on the subsidy for electricity service in the province of Manabí.

4) Considering the average real cost of the $\mathrm{kWh}$ served in the province of Manabí equivalent to 0.23 USD, it can be stated that the energy productivity of the photovoltaic plant in one year will have a value of 25185.00 USD.

\section{The social impact}

Social impact is an element that can hardly be achieved through traditional ways of implementing energy. Photovoltaic technology allows, like no other source, the relocation of the energy resource very close to the social actors that consume electricity, and this can be an influential element for the adoption of new positions of consumption and responsibility based on the preservation of resources and the adoption of patterns of energy use and expenditure appropriate to the real needs of work and people. The location of a photovoltaic power plant in the JENMER CIA LTDA service station fosters an important change in the social role of the institution, from being a simple energy consumer to an entity capable of generating a part of the electricity it consumes through the use of a clean and inexhaustible energy resource such as solar energy.

Pérez, A. V., Zambrano, F. I. C., Quiroz, A. M. V., Mieles, G. M., \& Viteri, C. G. F. V. (2021). Design of a photovoltaic power plant connected to the grid to cover the daytime energy demand of the Jenmer cia ltda service station. International Research Journal of Engineering, IT \& Scientific Research, 7(1), 10-24. https://doi.org/10.21744/irjeis.v7n1.1200 
The introduction of the technology makes the JENMER CIA LTDA service station a pioneer in the introduction of photovoltaic plants connected to the low voltage network, which undoubtedly contributes to raising the environmental image of the institution before Manabí society. The intensity, quality, and availability of the solar potential that affects the site where it is located in the JENMER CIA LTDA service station throughout the year allow the introduction of photovoltaic technology to generate electrical energy, with performance competitive with any other of existing technologies and generation sources, with an approximate cost of 0.06 USD / kWh served to consumption.

\section{Conclusion}

It is feasible from a technical, economic, environmental, and social point of view, to introduce photovoltaic technology connected to the low voltage network in the JENMER CIA LTDA service station, to reduce the amount of the electricity bill by $60 \%$ derived from the energy consumption of the conventional grid, which is one year can represent an approximate saving of 10,950.00 USD. The introduction of photovoltaic technology can generate other benefits associated with the protection of natural resources by avoiding the consumption of 27.4 tons of oil per year, as well as avoiding the emission of 98.55 tons of $\mathrm{CO}_{2}$ into the atmosphere in the same time frame.

\section{Conflict of interest statement}

The authors declared that they have no competing interests.

\section{Statement of authorship}

The authors have a responsibility for the conception and design of the study. The authors have approved the final article.

\section{Acknowledgments}

We are grateful to two anonymous reviewers for their valuable comments on the earlier version of this paper. 


\section{References}

Arauz, W. M. S., Cedeño, G. I., Chávez, S. S., Pérez, A. V., \& Gámez, M. R. (2017). Microgrid With a 3.4 kWp Photovoltaic System in the Universidad Técnica de Manabí. International Journal of Physical Sciences and Engineering, 1(2), 11-20.

Arauz, W. M. S., Gámez, M. R., Pérez, A. V., \& Fernández, M. C. (2016). Microgrids views from a geographic information system. System, 2454, 2261.

Cabeza, C.J.V. (2018). Estudio del potencial disponible en el edificio 3 para aumentar la generación por energía solar. Facultad de Ciencias Matemáticas, Físicas y Químicas. trabajo de titulación previo para obtener el título de Ingeniero Electricista, Repositorio de la biblioteca de la Universidad Técnica de Manabí.

Cedeno, M. L. D., Arteaga, M. G. D., Perez, A. V., \& Arteaga, M. L. D. (2017). Regulatory framework for renewable energy sources in Ecuador case study province of Manabi. International Journal of Social Sciences and Humanities (IJSSH), 1(2), 29-42.

Chilan, J. C. H., Perez, A. V., Gamez, M. R., García, A. A. M., \& Breffe, O. E. T. (2017). Use of Small Wind Turbines in Isolated Areas Social Impact. International Research Journal of Engineering, IT and Scientific Research, 3(2), 96-103.

Delgado, G.A.E. (2016). La energía fotovoltaica en la preparación de la sociedad para enfrentar un sismo de gran intensidad en la provincia de Manabí. Trabajo de diploma. Carrera de Ingeniería Elécrtrica. Facultad de Ciencias Matemática, Física y Química, Repositorio de la biblioteca de la Universidad Técnica de Manabí.

Dincer, I. (2000). Renewable energy and sustainable development: a crucial review. Renewable and sustainable energy reviews, 4(2), 157-175. https://doi.org/10.1016/S1364-0321(99)00011-8

El-Ghonemy, A. M. K. (2012). Retracted: water desalination systems powered by renewable energy sources, Review. https://doi.org/10.1016/j.rser.2011.11.002

Espinoza, V.A.E., \& Macías, M.E.F. (2016). Reducción de la factura eléctrica y el incremento de la eficiancia energética en la Unidad Educativa José Leonidas Delgado del cantón Rocafuerte. Trabajo de diploma. Carrera de Ingeniería Eléctrica. Facultad de Ciencias Matemática, Física y Química, Repositorio de la biblioteca de la Universidad Técnica de Manabí.

Fabjan, C., Garche, J., Harrer, B., Jörissen, L., Kolbeck, C., Philippi, F., ... \& Wagner, F. (2001). The vanadium redox-battery: an efficient storage unit for photovoltaic systems. Electrochimica Acta, 47(5), 825-831. https://doi.org/10.1016/S0013-4686(01)00763-0

Gabriela, IC, \& Susana, SC (2015). Implementation of photovoltaic technology connected to the grid to supply electricity to the second and third floors of building No. 3 of full-time teachers of the Technical University of Manabí, energy saving and efficiency.

Gámez, M. R., Pérez, A. V., Wilber, M., \& Guardarrama, J. R. (2017). El Potencial Solar y la Generación Distribuida en la Provincia de Manabí en el Ecuador. Revista de Investigaciones en Energía, Medio Ambiente y Tecnología: RIEMAT ISSN: 2588-0721, 2(2), 41-45.

Giraudy Arafet, CM, Massipe Cano, I., Rodríguez Rivera, R., Rodríguez Gámez, M., \& Vázquez Pérez, A. (2014). Feasibility of installing photovoltaic systems connected to the grid. Energy Engineering , 35 (2), 141-148.

Joerissen, L., Garche, J., Fabjan, C., \& Tomazic, G. (2004). Possible use of vanadium redox-flow batteries for energy storage in small grids and stand-alone photovoltaic systems. Journal of power sources, 127(1-2), 98-104. https://doi.org/10.1016/j.jpowsour.2003.09.066

Macías, M.I.O., \& Macías, C.S.V. (2016). Papel de la energía fotovoltaica en la reducción de desastres naturales en la provincia de Manabí. Tesis de diploma. Carrera de Ingeniería Eléctrica. Facultad de Ciencias Matemática, Física y Química, Repositorio de la biblioteca de la Universidad Técnica de Manabí.

María, R. G. (2015). SIGDES. Sistema de Información Geográfica para el Desarrollo Sostenible. Facultad de Ciencias Matemáticas, Físicas y Químicas de la Universidad Técnica de Manabí.

Medveczky, O.D., \& Ochoa, C.J. (2012). Tesis previa a la obtención de título de ingeniero eléctrico. Universidad de Cuenca.

Murray, S., \& Larry, S. (2009). Disponible. 577

Panwar, N. L., Kaushik, S. C., \& Kothari, S. (2011). Role of renewable energy sources in environmental protection: A review. Renewable and sustainable energy reviews, 15(3), 1513-1524. https://doi.org/10.1016/j.rser.2010.11.037

Pérez, A. V., Castillo, G. A. L., Alava, L. A. C., \& Chilan, J. C. H. (2016). The regulatory framework for renewable energy sources. International Research Journal of Management, IT and Social Sciences, 3(11), 8-21.

Pérez, A. V., Zambrano, F. I. C., Quiroz, A. M. V., Mieles, G. M., \& Viteri, C. G. F. V. (2021). Design of a photovoltaic power plant connected to the grid to cover the daytime energy demand of the Jenmer cia ltda service station. International Research Journal of Engineering, IT \& Scientific Research, 7(1), 10-24. https://doi.org/10.21744/irjeis.v7n1.1200 
Perez, A. V., Gámez, M. R., Viteri, C. G. V., \& Quiroz, A. M. V. (2017). Community power as a driving force for sustainable local development. Journal of College and University. This is an open access article under the, 2454, 2261.

Quijije A Wilson S, \& Reina V Jefferson D. (2016). Implementación de una microrred fotovoltaica conectada a la red, para suministrar energía eléctrica al primer piso del edificio no. 3 de Docentes a Tiempo Completo de la Universidad Técnica de Manabí, el ahorro y la eficiencia energética. Informe escrito del trabajo de titulación para obtener el Título de Ingeniero Eléctrico. Modalidad de Trabajo Comunitario y Cambio de la Matriz Energética. Repositorio de la Biblioteca de la Universidad Técnica de Manabí.

Rodríguez Gámez, M., Vázquez Pérez, A., Castro Fernández, M., \& Vilaragut Llanes, M. (2013). Photovoltaic systems and land use planning. Energy Engineering , 34 (3), 247-259.

Rodríguez, G.M., \& Vázquez, P.A. (2018). Libro Guía de la Energía Solar en la provincia de Manabí. Repositorio de la biblioteca central de la Universidad Técnca de Manabí. Carrera de Ingeniería Eléctrica. Facultad de Ciencias Matemáticas Físicas y Químicas.

Rodriguez, María; Vázquez, P Antonio; Saltos, A Wilbert M \& Castillo, J. Washington C. (2016). Sustainable Transformation of Energy Matrix. International Research Journal of Engineering, IT \& Scientific Research (IRJEIS), 2(9), 28-33.

Sarmiento Sera, A., Rodríguez Gámez, M., Castillo Castillo, O., \& Vázquez Pérez, A. (2014). Integrated energy systems with renewable sources, requirements and options. Energy Engineering , 35 (1), $70-78$.

Soto, I. E. P. (2005). Celdas fotovoltaicas en generación distribuida. Santiago de Chile, 7.

Van, D.W. (2002). La cooperación transnacional, un instrumento al servicio del desarrollo rural. Cooperación internacional entre territorios rurales. Consultado diciembre 2017.

Zahedi, A. (2006). Solar photovoltaic (PV) energy; latest developments in the building integrated and hybrid PV systems. Renewable Energy, 31(5), 711-718. https://doi.org/10.1016/j.renene.2005.08.007 